\title{
Gender Differences in the Effect of Chronic Illness on Employment Status in Kenya
}

\author{
Dr. Phyllis Mumia Machio \\ School of Economics, University of Nairobi, Kenya
}

doi: 10.19044/esj.2016.v12n19p338 URL:http://dx.doi.org/10.19044/esj.2016.v12n19p338

\begin{abstract}
The burden of illness in Kenya has been high and rising with chronic illness becoming an important contributor to disease burden. Grossman (1972) viewed stock of health as an investment good that determines total healthy time available for market activities. Illness, therefore, can reduce total amount of healthy time causing individual's to prefer flexible types of employment. This study estimates the effect of chronic illness on probability of participating in various type of employment in Kenya using the Kenya integrated household budget survey data. Multinomial probit models were used to model choice between wage employment, non-agricultural selfemployment, agricultural self-employment and not working since data did not support the multinomial logit's assumption of IIA. The results indicated that compared to not working, chronic illness reduced likelihood of individuals working in wage employment and in agricultural self-employment. When the analysis was disaggregated by gender, results showed that while chronic illness significantly reduced women's likelihood of working in wage employment and in agricultural self-employment, it did not significantly influence men's choice of employment type. Policies need to be put in place by the government to control the up rise in chronic illnesses. This can be through promotion of health lifestyles by advocating for consumption of healthy diets, physical activity and non tobacco consumption. The government can ensure proper management of chronic illnesses such as HIV/AIDS, diabetes, high blood pressure by making available at subsidized prices management drugs. Reducing chronic illness incidences not only increases utility of the individuals, but also affect labor market choices.
\end{abstract}

Keywords: Employment rate, gender differences

\section{Introduction}

Economic growth mainly occurs through labor reallocation as workers move from low productivity jobs to higher productivity jobs leading to 
increased output (World Bank, 2012). In Kenya, labor market statistics show that the share of wage employment in total employment has shrank while the share of non-agricultural self employment has risen. In 1998, wage employment accounted for $24.4 \%$ of total employment shrinking to $13.8 \%$ in 2005. Non-agricultural self employment, which accounted for $32.4 \%$ of total employment in 1998, rose to $45.5 \%$ in 2015 . The share of agricultural self employment declined marginally over this period (Republic of Kenya [RoK], 2003; 2008). Similar trends are observed when the data is disaggregated by gender except that the share of men in agricultural self employment rises marginally. For both years, the proportion of men in wage employment and non-agricultural self employment was higher than that of women though the proportion of women in agricultural self-employment was higher than that of men.

Table 1: Labor Market Statistics for Kenya by Gender

\begin{tabular}{|l|r|r|r|r|r|r|}
\hline \multirow{2}{*}{ Variables } & \multicolumn{2}{|c|}{$\mathbf{1 9 9 8}$} & \multicolumn{2}{|r|}{$\mathbf{2 0 0 5}$} \\
\cline { 2 - 7 } & Total & Men & Women & Total & Men & Women \\
\hline $\begin{array}{l}\text { Share of wage employment in } \\
\text { total employment (\%) }\end{array}$ & 24.4 & 17.6 & 6.8 & 13.8 & 9.5 & 4.3 \\
\hline $\begin{array}{l}\text { Share of non-agricultural self- } \\
\text { employment in total employment } \\
(\%)\end{array}$ & 32.4 & 17.8 & 14.7 & 45.5 & 23.8 & 21.8 \\
\hline $\begin{array}{l}\text { Share of agricultural self- } \\
\text { employment in total employment } \\
(\%)\end{array}$ & 43.2 & 17.3 & 25.9 & 40.7 & 18.5 & 22.2 \\
\hline
\end{tabular}

Source: Republic of Kenya, 2003; 2008

Grossman (1972) viewed stock of health as an investment good that determines total number of healthy time to work and earn a living. Illness may reduce the amount of healthy time available for work. This may cause individuals to prefer employments with flexible working hours. Illness may therefore cause individuals to move from wage employment to more flexible forms of employment such as non agricultural self employment. Non agricultural self employment in Africa is mainly dominated by the poor (Banerjee \& Duflo, 2007. Earnings in such forms of employment are lower and they have fewer social protection programs compared to wage employment (Fields, 2014). The differentiating factor therefore between the poor and non poor is not whether or not they are employed but rather how much is earned from the work they do (Fields, 2014).

Kenya has been experiencing a high and rising burden of disease. Communicable and non communicable diseases continue to rob Kenyans off good health with morbidity increasing substantially by $66 \%$ between 2008 and 2014 (Kenya National Bureau of Statistics [KNBS], 2013; 2015). While malaria has been the leading cause of morbidity over the years, it has since 2012 been over taken by diseases of the respiratory system. The burden of ill 
health due to non communicable diseases (NCDs such as cancers, diseases of the respiratory system, digestive diseases among others) has been increasingly rising steadily (Ministry of Health $[\mathrm{MoH}], 2014)$. About half of inpatient mortality and $50-70 \%$ of all inpatient admissions between 2002 and 2008 were due to NCDs (Ministry of Medical Services and Ministry of Public Health and Sanitation [MOMS and MOPHS], 2012).

Previous studies on relationship between health status and type of employment have mainly taken two approaches. The first set of studies examines effect of health status on transition across various labor market states (Parker \& Rougier, 2007; Zissimopoulos \& Karoly, 2007; Giandrea, Cahill \& Quinn, 2008; Fuchs, 1982; Zucchelli, Harris \& Xueyan, 2012). Most of these studies are on developed countries which have rich panel data sets to allow such analysis. The other set of studies examine how health status is related with an individual's type of employment. Such studies have been conducted using data from developing countries (Bridges \& Lawson, 2008; Thomas \& Strauss, 1997). There are therefore limited studies on developing countries. This study adds to literature by estimating the effects of chronic illness on choice between wage employment, agricultural self-employment and non-agricultural selfemployment. The distinction between agricultural and non-agricultural self employment is important given that in Africa these are two distinct sectors that absorb a large number of workers independently. Chronic illnesses tend to be long term and thus are likely to influence long term decisions.

\section{Methodology}

The model has four employment states $(S)$ : wage employment $(S=1)$, non-agricultural self-employment $(S=2)$, agricultural selfemployment $(S=3)$ and not working $(S=4)$. That is, in addition to the three employment types, a category for individual not working is included to make the categories exhaustive. Following Robertson and Symons (1990) and Mwabu and Evenson (1997), an individual $i$ attaches a subjective utility $U_{i s}$ on each employment state $S$. An individual chooses employment state $S$ if

$U_{i s}>U_{\text {iM }}$

Where $M$ is all other employment states except $S$. The utility index $U_{i s}$ comprises of a systematic part $\left(U_{i s}^{*}\right)$ and an unobservable individual part $\left(\varepsilon_{i s}\right)$. Thus,

$U_{i S}=U_{i S}^{*}+\varepsilon_{i S}$

Where $\varepsilon_{i s}$, captures both random aspects of individual $i$ and the possibility that the model may not predict choice of employment state by 
individual $i$ with certainty. The utility index is related to a set of explanatory variables including health status as follows

$$
U_{i s}=\beta_{s} Z_{i}+\delta H_{i}
$$

Where, $Z_{i}$ is a vector of personal and socio economic characteristics of individual $i, H_{i}$, is health status of individual $i$. Assuming $\varepsilon_{i s}$ as an extreme value probability distribution (Wooldridge, 2002), the probability of individual $i$ choosing employment state $S$ can be written as

$$
P_{i s}=\frac{\exp \left(U_{i s}\right)}{\sum_{M} \exp \left(U_{i M}\right)}
$$

We can divide the numerator and denominator of equation (3) by $\exp U_{i s}$ so that the equation is expressed in terms of utility difference

$$
P_{i s}=\left\{\exp \left(U_{i m}-U_{i s}\right)\right\}^{-1}
$$

Equation (5) is estimated using maximum likelihood and the associated $\log$ likelihood function is given as $\ln L=\sum_{i} \sum_{M} d_{i s} \ln \left\{\exp \left(U_{i M}-U_{i s}\right)^{-1}\right.$

\subsection{Data}

This study used data from the Kenya Integrated Household Budget Survey (KIHBS) 2005/6. This is the most recent nationally representative survey conducted by the Kenya National Bureau of Statistics (KNBS). The survey was conducted in 1,343 randomly selected clusters in Kenya and comprised 861 rural and 482 urban clusters. These were the primary sampling units. A sample size of 13,430 households was selected that comprised 10 households randomly selected with equal probability in each cluster. The sample sizes in rural and urban areas were 8,610 and 4,820 households respectively. The survey collected information on various health indicators including morbidity. Respondents were asked if they suffered from any form of chronic illness and if so which chronic illness they suffered from ${ }^{1}$. On the labor market, the respondents were asked to state whether they worked for pay, were on leave, were on sick leave, worked on own business, worked on own agricultural holding, were seeking work, doing nothing, retired, homemakers or incapacitated during the past 7 days.. Employment type was generated from this question. Information on individual and household characteristics was also collected.

\footnotetext{
${ }^{1}$ Chronic illnesses considered in this study included: HIV/AIDS, diabetes, asthma, cancer, high blood pressure, arthritis, stomach disorders, nerve disorders, bilharzias etc.
} 


\section{Results and discussions}

\subsection{Descriptive statistics}

Table 1 presents the descriptive statistics. Higher prevalence of chronic illnesses is reported in females compared to the males. While $16 \%$ of the female respondents reported to have chronic illness, $10 \%$ of the males reported to have chronic illness. About a third of the respondents had no formal education and only 14 percent reported to have tertiary education level. There is not much variation in the distribution of education levels by gender, but generally a higher proportion of males report higher levels of education (secondary and tertiary education levels) and a higher proportion of females report lower levels of education (No education and primary education). Approximately two-thirds of the respondents lived in the rural areas, had no child and were married. 
Table 1:Descriptive Statistics of Variables Included in the Employment Model, Full Sample

\begin{tabular}{|c|c|c|c|}
\hline \multirow[t]{2}{*}{ Variables } & \multicolumn{3}{|c|}{ Mean (Standard deviation) } \\
\hline & $\begin{array}{l}\text { Male } \\
\text { sample }\end{array}$ & $\begin{array}{l}\text { Female } \\
\text { sample }\end{array}$ & $\begin{array}{l}\text { Full } \\
\text { sample }\end{array}$ \\
\hline \multicolumn{4}{|l|}{ Health Status } \\
\hline Chronic illness (=1 if an individual reported having chronic illness, 0 otherwise) & $0.10(0.29)$ & $0.16(0.36)$ & $0.13(0.34)$ \\
\hline \multicolumn{4}{|l|}{ Education } \\
\hline No formal education (=1 if an individual reported to have no formal education, 0 otherwise) & $0.31(0.46)$ & $0.37(0.48)$ & $0.35(0.48)$ \\
\hline Primary education (=1 if an individual reported having primary education, 0 otherwise) & $0.31(0.46)$ & $0.32(0.47)$ & $0.32(0.47)$ \\
\hline Secondary education (=1 if an individual reported having secondary education, 0 otherwise) & $0.20(0.40)$ & $0.17(0.38)$ & $0.18(0.39)$ \\
\hline Tertiary education (=1 if an individual reported having tertiary education, 0 otherwise) & $0.18(0.39)$ & $0.14(0.35)$ & $0.14(0.35)$ \\
\hline Age & $34(12)$ & $35(12)$ & $34(12)$ \\
\hline \multicolumn{4}{|l|}{ Marital status } \\
\hline Marital status (=1 if an individual reported to be married, 0 otherwise) & $0.64(0.48)$ & $0.61(0.49)$ & $0.62(0.49)$ \\
\hline \multicolumn{4}{|l|}{ Children below 5 years } \\
\hline No children (=1 if a household reported having no child below 5 years, 0 otherwise) & $0.59(0.49)$ & $0.57(0.50)$ & $0.56(0.50)$ \\
\hline One child (=1 if a household reported having 1 child below 5 years, 0 otherwise) & $0.23(0.42)$ & $0.25(0.43)$ & $0.24(0.43)$ \\
\hline Two or more children (=1 if a household reported having 2 or more children below 5 years, 0 otherwise & $0.18(0.38)$ & $0.18(0.39)$ & $0.20(0.40)$ \\
\hline \multicolumn{4}{|l|}{ Other variables } \\
\hline Rural area ( 1 if an individual reported to be living in the rural area, 0 otherwise & $0.65(0.48)$ & $0.70(0.46)$ & $0.70(0.47)$ \\
\hline Transfers (=1 if a household reported receiving transfers, 0 otherwise) & $0.68(0.47)$ & $0.69(0.46)$ & $0.67(0.46)$ \\
\hline Sample size & 8411 & 9223 & 17634 \\
\hline
\end{tabular}

Source: Author, based on KIHBS data (Republic of Kenya, 2007) Standard errors in parenthesis 


\subsection{Multinomial probit estimates}

This section presents maximum likelihood estimates from the multinomial probit model with an emphasis on the effect of illness on probability of participating in wage employment, in non-agricultural selfemployment and in agricultural self-employment relative to not working. Multinomial probit model was used because the multinomial logit has restrictive assumption of independence of irrelevant alternatives (IIA). The assumption states that the odds of being in employment state, $S$ over employment state, $M$ are independent of all other employment states and number of employment states. A Hausman test rejected the null hypothesis that IIA property holds. The details of the test are presented in Appendix Tables A1. In addition, tests of whether any of the four employment states could be combined were conducted (Appendix Table A2). The results showed that the null hypothesis that the categories could be combined could not be rejected favoring retaining four employment outcomes.

Test for poolability of the data, that is, whether it was appropriate to estimate the male and female employment status equations separately, was done Details are in appendix Table A3. To carry out the test, the independent variables were interacted with the gender dummy and the joint significance of these interaction terms tested. The $\chi^{2}$ statistic, with 36 degrees of freedom was 931.4 ( $\mathrm{p}$-value $=0.000$ ). Therefore, the null hypothesis that there is no significant difference in the estimated male and female coefficients was rejected. Thus, it was appropriate to estimate separate equations for the male and female samples.

Table 4 presents the marginal effects of multinomial probit model of employment status. The results show that individuals with chronic illness have a lower chance than non ill persons of being in wage employment and in agricultural self-employment relative to not working. The likelihood of wage employment and agricultural self-employment is lower by 4.7 and 3.7 percentage points respectively for individuals with chronic illness. The illness effect is higher for women. Chronic illness reduces their chance of wage employment and agricultural self-employment by 5 and 4.7 percentage points respectively. For men, however, the effect of chronic illness on all the three types of employment is insignificant. These results imply that a 2 to 5 percent reduction in chronic illness will cause wage employment and agricultural self-employment to increase by between 10 to 25 percent.

The negative effect of chronic illness on chance of wage employment and agricultural self-employment can be attributed to the fact that wage employment is usually characterized by non flexible working hours and a standard work week, yet chronically ill individuals may require a flexible work schedule depending on type and severity of the chronic illness. Also since illness may affect an individual's capacity to fulfill job requirements, 
hence productivity, chronically ill individuals may be less competitive for wage employment. Further, work in the agricultural sector relies heavily on physical ability yet chronic illness may make individuals weak and thus it is difficult for them to perform agricultural tasks.

These findings are in line with those of Bridges and Lawson (2008) who found that illness reduces the likelihood of being in the wage employment especially for women in Uganda. Zissimopoulos and Karoly (2007) also reported similar findings that illness increases the likelihood of individuals switching from full time wage employment to self employment. This, they argue may be because self employment is less formal than wage employment allowing workers here to take time off when ill. Similarly this could be because jobs in self employment are open to those in ill health unlike those in wage employment.

The results however contradict those of Giandrea. et al., (2008) who found that men in poor health or men whose spouse were in poor health were less likely than other similar respondents to switch from full time wage employment to self employment. This may be associated with the benefits of wage employment such as health insurance. This study also finds that chronic illness does not significantly influence men's choice of type of employment contrary to Zissimopoulos and Karoly (2007) who find that men are the most affected by illness. This may reflect ability to make accommodations in work employment when self employed as opposed to when wage employment.

Education increases the probability of wage employment. Individuals with tertiary education are 28 percentage points more likely to be in wage employment compared to those with no formal education. The effect of tertiary education on wage employment is even higher for women. While tertiary education increases men's probability of wage employment by 21 percentage points it increases women's probability of wage employment by 34 percentage points relative to those with no formal education.

Unlike for wage employment, however, tertiary education reduces the probability of self employment. It reduces the likelihood of individuals being in the non-agricultural and agricultural self-employment by 4 percentage points and 15 percentage points respectively. The tertiary educational effects on probability of agricultural self-employment are higher for women at 16 percentage points compared to men at 14 percentage points. Further, for women, secondary education also significantly reduces the likelihood of being employed in the agricultural self-employment. Previous studies on Kenya also found that education is a key determinant of sector participation (Kabubo- Mariara, 2003; Atieno, 2006; Nyaga, 2010; Wambugu, 2011). Studies outside Kenya also support the finding that 
education is a significant determinant of type of employment (Bridges \& Lawson, 2008; Vijverberg, 1993; Dimova, Nordman \& Roubaud, 2010; Glick \& Sahn, 1997).

Age and age squared are used to capture experience and lifecycle effects. The marginal effects show that age increases the likelihood of wage and non-agricultural self-employment though a negative sign on the square term indicates that much older individuals are less likely to be in wage employment and agricultural self-employment. The findings are in line with Dimova et al. (2010); Wambugu (2011); Nyaga (2010); Kabubo-Mariara (2003) and Atieno (2006) who found a concave relation between age variables and sector participation.

Men are more likely than women to be in wage employment and in non-agricultural self-employment. Their probability of wage employment and non-agricultural self-employment is higher than that of women by 20 and 2 percentage points respectively. Men are however 4 percentage points less likely to be in agricultural self-employment. In line with this study, Nyaga (2010) found that men were more likely to be in the formal sector, while Glick and Sahn (1997) found that women were more likely than men to be in wage employment.

Married men are more likely than unmarried men to be in wage employment and non-agricultural self-employment. The chance of a married man being in wage employment and in non-agricultural self-employment is 10 percentage points higher than for a comparable but unmarried one. A married woman, on the other hand, is less likely than an unmarried women to be in wage employment but more likely to be in agricultural selfemployment. Compared to their unmarried counterparts, a married woman is 16 percentage points less likely to be in wage employment and 3 percentage points more likely to be in the agricultural self-employment. Similar findings are shared by Wambugu (2011). Kabubo-Mariara (2003) and Wamuthenya (2010) found that married men had higher likelihood of working in the formal sector relative to the informal sector. The negative effect of marriage on chance of women being employed in wage employment may reflect employer's prejudice against female employees because of fear that they will interupt their careers due to family responsibilities.

Presence of children below 5 years in a household reduces the likelihood of wage employment. Individuals living in a household with children below 5 years are 4 percentage points less likely to be in wage employment relative to individuals living in households with no such children. Surprisingly however, the effect of children below 5 years on the probability of wage employment is higher for men than women. While children reduce a man's chance of wage employment by 8 percentage points, they only reduce a woman's chance by 3 percentage points. This 
finding are in line with Dimova et al. (2010) that presence of children (0-5 years) increased the likelihood of men being in self employment and that the effect is higher for men than women. Kabubo-Mariara (2003) also found that presence of children 0-6 years reduced the likelihood of men working in wage employment relative to self employment. 
Table 4: Estimates of Effect of Chronic Illness on Employment status, Marginal Effects

\begin{tabular}{|c|c|c|c|c|c|c|c|c|c|}
\hline \multirow[b]{2}{*}{ Variable } & \multicolumn{3}{|c|}{ Full sample } & \multicolumn{3}{|c|}{ Male sample } & \multicolumn{3}{|c|}{ Female sample } \\
\hline & $\begin{array}{l}\text { Wage } \\
\text { employment }\end{array}$ & $\begin{array}{l}\text { Non- } \\
\text { agricultural } \\
\text { self - } \\
\text { employment }\end{array}$ & $\begin{array}{l}\text { Agricultural } \\
\text { self- } \\
\text { employment }\end{array}$ & $\begin{array}{l}\text { Wage } \\
\text { employment }\end{array}$ & $\begin{array}{l}\text { Non- } \\
\text { agricultural } \\
\text { self- } \\
\text { employment }\end{array}$ & $\begin{array}{l}\text { Agricultural } \\
\text { Self- } \\
\text { employment }\end{array}$ & $\begin{array}{l}\text { Wage } \\
\text { employment }\end{array}$ & $\begin{array}{l}\text { Non- } \\
\text { agricultural } \\
\text { self - } \\
\text { employment }\end{array}$ & $\begin{array}{l}\text { Agricultural } \\
\text { self -employment }\end{array}$ \\
\hline Chronic illness & $\begin{array}{l}-0.0465^{* * *} \\
{[0.014]}\end{array}$ & $\begin{array}{l}0.0102 \\
{[0.011]}\end{array}$ & $\begin{array}{l}-0.0317 * * \\
{[0.013]}\end{array}$ & $\begin{array}{l}-0.0244 \\
{[0.023]}\end{array}$ & $\begin{array}{l}-0.0057 \\
{[0.017]}\end{array}$ & $\begin{array}{l}-0.0169 \\
{[0.020]}\end{array}$ & $\begin{array}{l}-0.0548^{* * *} \\
{[0.014]}\end{array}$ & $\begin{array}{l}0.0157 \\
{[0.015]}\end{array}$ & $\begin{array}{l}-0.0471^{* * *} \\
{[0.017]}\end{array}$ \\
\hline Age & $\begin{array}{l}0.0378^{* * *} \\
{[0.003]}\end{array}$ & $\begin{array}{l}0.0157 * * * \\
{[0.002]}\end{array}$ & $\begin{array}{l}-0.0081^{* * *} \\
{[0.002]}\end{array}$ & $\begin{array}{l}0.0386^{* * *} \\
{[0.004]}\end{array}$ & $\begin{array}{l}0.0059^{*} \\
{[0.003]}\end{array}$ & $\begin{array}{l}-0.0196 * * * \\
{[0.003]}\end{array}$ & $\begin{array}{l}0.0263^{* * *} \\
{[0.003]}\end{array}$ & $\begin{array}{l}0.0223^{* * *} \\
{[0.003]}\end{array}$ & $\begin{array}{l}0.0065^{*} \\
{[0.004]}\end{array}$ \\
\hline Primary education & $\begin{array}{l}0.014 \\
{[0.012]}\end{array}$ & $\begin{array}{l}0.0043 \\
{[0.009]}\end{array}$ & $\begin{array}{l}0.0015 \\
{[0.011]}\end{array}$ & $\begin{array}{l}-0.0122 \\
{[0.018]}\end{array}$ & $\begin{array}{l}0.0056 \\
{[0.013]}\end{array}$ & $\begin{array}{l}-0.0087 \\
{[0.015]}\end{array}$ & $\begin{array}{l}0.0245 \\
{[0.015]}\end{array}$ & $\begin{array}{l}0.0038 \\
{[0.013]}\end{array}$ & $\begin{array}{l}0.0198 \\
{[0.015]}\end{array}$ \\
\hline Secondary education & $\begin{array}{l}0.0345^{* *} \\
{[0.014]}\end{array}$ & $\begin{array}{l}0.0006 \\
{[0.011]}\end{array}$ & $\begin{array}{l}-0.0295^{* *} \\
{[0.013]}\end{array}$ & $\begin{array}{l}-0.0102 \\
{[0.020]}\end{array}$ & $\begin{array}{l}0.0167 \\
{[0.016]}\end{array}$ & $\begin{array}{l}-0.0252 \\
{[0.017]}\end{array}$ & $\begin{array}{l}0.0691 * * * \\
{[0.019]}\end{array}$ & $\begin{array}{l}-0.0146 \\
{[0.015]}\end{array}$ & $\begin{array}{l}-0.0254 \\
{[0.020]}\end{array}$ \\
\hline Tertiary education & $\begin{array}{l}0.2807 * * * \\
{[0.017]}\end{array}$ & $\begin{array}{l}-0.0411^{* * *} \\
{[0.010]}\end{array}$ & $\begin{array}{l}-0.1507^{* * *} \\
{[0.012]}\end{array}$ & $\begin{array}{l}0.2117^{* * *} \\
{[0.022]}\end{array}$ & $\begin{array}{l}-0.0218 \\
{[0.015]}\end{array}$ & $\begin{array}{l}-0.1394^{* * *} \\
{[0.016]}\end{array}$ & $\begin{array}{l}0.3428 * * * \\
{[0.025]}\end{array}$ & $\begin{array}{l}-0.0630^{* * * *} \\
{[0.013]}\end{array}$ & $\begin{array}{l}-0.1595^{* * *} \\
{[0.018]}\end{array}$ \\
\hline $\begin{array}{l}\text { Marital status } \\
\text { (married=1 }\end{array}$ & $\begin{array}{l}-0.0574 * * * \\
{[0.012]}\end{array}$ & $\begin{array}{l}0.0621 * * * \\
{[0.009]}\end{array}$ & $\begin{array}{l}0.0049 \\
{[0.012]}\end{array}$ & $\begin{array}{l}0.0965^{* * * *} \\
{[0.019]}\end{array}$ & $\begin{array}{l}0.1021^{* * *} \\
{[0.014]}\end{array}$ & $\begin{array}{l}-0.0122 \\
{[0.018]}\end{array}$ & $\begin{array}{l}-0.1620 * * * \\
{[0.014]}\end{array}$ & $\begin{array}{l}0.0291^{* *} \\
{[0.011]}\end{array}$ & $\begin{array}{l}0.0199 \\
{[0.015]}\end{array}$ \\
\hline Presence of children 0-5 & ears (no child i & reference categ & & & & & & & \\
\hline 1 child & $\begin{array}{l}-0.0019 \\
{[0.011]}\end{array}$ & $\begin{array}{l}0.0135 \\
{[0.009]}\end{array}$ & $\begin{array}{l}-0.0421^{* * *} \\
{[0.011]}\end{array}$ & $\begin{array}{l}-0.0217 \\
{[0.017]}\end{array}$ & $\begin{array}{l}0.0289 * * \\
{[0.013]}\end{array}$ & $\begin{array}{l}-0.0254^{*} \\
{[0.015]}\end{array}$ & $\begin{array}{l}0 \\
{[0.013]}\end{array}$ & $\begin{array}{l}-0.0072 \\
{[0.012]}\end{array}$ & $\begin{array}{l}-0.0534^{* * *} \\
{[0.015]}\end{array}$ \\
\hline 2 or more children & $\begin{array}{l}-0.0415^{* * *} \\
{[0.013]}\end{array}$ & $\begin{array}{l}-0.0062 \\
{[0.010]}\end{array}$ & $\begin{array}{l}0.0016 \\
{[0.012]}\end{array}$ & $\begin{array}{l}-0.0758^{* * * *} \\
{[0.019]}\end{array}$ & $\begin{array}{l}-0.0039 \\
{[0.015]}\end{array}$ & $\begin{array}{l}0.0322 * \\
{[0.018]}\end{array}$ & $\begin{array}{l}-0.0319 * * \\
{[0.015]}\end{array}$ & $\begin{array}{l}-0.0135 \\
{[0.014]}\end{array}$ & $\begin{array}{l}-0.0185 \\
{[0.017]}\end{array}$ \\
\hline Rural area & $\begin{array}{l}-0.1777^{* * *} \\
{[0.010]}\end{array}$ & $\begin{array}{l}-0.1342^{* * *} \\
{[0.008]}\end{array}$ & $\begin{array}{l}0.4053 * * * \\
{[0.007]}\end{array}$ & $\begin{array}{l}-0.2195^{* * * *} \\
{[0.014]}\end{array}$ & $\begin{array}{l}-0.1158^{* * * *} \\
{[0.011]}\end{array}$ & $\begin{array}{l}0.3775^{* * * *} \\
{[0.010]}\end{array}$ & $\begin{array}{l}-0.1055^{* * * *} \\
{[0.012]}\end{array}$ & $\begin{array}{l}-0.1453^{* * * *} \\
{[0.012]}\end{array}$ & $\begin{array}{l}0.4193^{* * *} \\
{[0.011]}\end{array}$ \\
\hline Transfers & $\begin{array}{l}0.0329 * * * \\
{[0.010]}\end{array}$ & $\begin{array}{l}0.0166^{* *} \\
{[0.008]}\end{array}$ & $\begin{array}{l}-0.0744 * * * \\
{[0.010]}\end{array}$ & $\begin{array}{l}0.0409^{* * * *} \\
{[0.015]}\end{array}$ & $\begin{array}{l}0.008 \\
{[0.011]}\end{array}$ & $\begin{array}{l}-0.0632 * * * \\
{[0.014]}\end{array}$ & $\begin{array}{l}0.0252^{* *} \\
{[0.012]}\end{array}$ & $\begin{array}{l}0.0249 * * \\
{[0.011]}\end{array}$ & $\begin{array}{l}-0.0876^{* * *} \\
{[0.015]}\end{array}$ \\
\hline Number of observations & 11,230 & 11,230 & 11,230 & 5,880 & 5,880 & 5,880 & 5,350 & 5,350 & 5,350 \\
\hline $\operatorname{LR} \chi^{2}$ & 3691 & 3691 & 3691 & 1685 & 1685 & 1685 & 1754 & 1754 & 1754 \\
\hline P-value & 0.000 & 0.000 & 0.000 & 0.000 & 0.000 & 0.000 & 0.000 & 0.000 & 0.000 \\
\hline
\end{tabular}




\section{Conclusion and policy implication}

The effect of chronic illness on the probability of participating in various employment types was estimated in this paper using multinomial probit models. The estimated model had four employment states: wage employment, non-agricultural self-employment, agricultural self-employment and not working. The use of multinomial probit was justified because the data did not support the multinomial logit's assumption of IIA.

From the empirical analysis, chronic illness constrains participation in various employment types especially for women. Chronically ill women are less likely to be in wage employment and in agricultural selfemployment. Their likelihood of participating in wage employment and in agricultural self-employment is lower by 5 percentage points compared to those who are not ill. Chronic illness is not a significant determinant of men's probability of participating in various employment types. Simulations show that a 2 to 5 percent reduction in chronic illness increases wage employment and agricultural self-employment by between 10 to 25 percent.

The findings in this paper imply that illness especially chronic illness constrains women access to wage employment and agricultural self employment. Wage employment is usually characterized by job security and benefits such as pension plan and health insurance (Agenor, 1996). Earnings in wage employment are also higher (Fields, 2014). Non agricultural self employment is mainly dominated by the poor (Banerjee \& Duflo, 2007). By acting as a constraint to women participating in wage employment, illness therefore, exposes women to poverty. There is therefore need for government to control and manage chronic illness not only because such policies will increase utility of the population but also because they have labor market implications. Awareness creation on healthy lifestyles should be promoted especially on healthy diets, physical activity and non tobacco use. It is also important to increase awareness on managing chronic illnesses such as HIV/AIDs, diabetes, high blood pressure, etc. Making available drugs on managing these chronic illnesses will also go a long way in curtailing their negative effects on the population.

\section{References:}

Agenor, P.R..(1996). Labor market and economic adjustment. IMF Working Papers WP 95/125. International Monetary Fund (IMF).

Atieno, R.. (2006). Female participation in the labor market: the case of informal sector in Kenya. AERC Research Paper No. 157. Nairobi: African Economic Research Consortium (AERC).

Banerjee, A.V., \& Duflo, E. (2007). The economic lives of the poor. Journal of Economic Perspectives, 21, 141-168 
Bridges, S., \& Lawson, D. (2008). A Gender-based investigation into the determinants of labour market outcomes: evidence from Uganda. Journal of African Economies, 18, 461-495.

Dimova, R., Nordman, C.J., \& Roubaud, F. (2010). Allocation of labor in urban West Africa: insights from the pattern of labor supply and skill premiums. Review of Development Economics, 14, 74-92.

Fields, G.S. (2014). Self-Employment and poverty in developing countries. IZA World of Labor, 60

Giandrea, M.D., Cahill, K.E., \& Quinn, J.F. (2008). Self-Employment transitions among older American workers with career jobs. Bureau of Labor Statistics Working Paper 418.

Glick, P., \& Sahn, D. (1997). Gender and education impacts on the employment and earnings in West Africa: evidence from Guinea. Economic Development and Cultural Change, 45, 793-824.

Grossman, M. (1972) On the concept of health capital and the demand for health. Journal of Political Economy, 80, 223-255.

Kabubo-Mariara, J. (2003) Wage determination and the gender wage gap in kenya: any evidence of gender discrimination? AERC Research Paper 132. Nairobi: African Economic Research Consortium (AERC).

Kenya National Bureau of Statistics. (2013) Economic survey 2013. Nairobi: Kenya National Bureau of Statistics.

Kenya National Bureau of Statistics. (2015) Economic Survey 2015. Nairobi: Kenya National Bureau of Statistics.

Ministry of Medical Services and Ministry of Public Health and Sanitation. (2012) Kenya health policy 2012-2030. Nairobi, Kenya

Mwabu, G., \& Evenson, R.E. (1997). A model of occupational choice applied to rural kenya. African Development Review, 9, 1-14.

Nyaga, K.R. (2010). Earnings and employment sector choice in Kenya. AERC Research Paper 199. Nairobi: African Economic Research Consortium (AERC).

Parker, S.C., \& Rougier, J.C. (2007). The Retirement behaviour of selfemployed in Britain. Applied Economics, 39, 697-713.

Republic of Kenya (2003) Report of 1998/99 labor force survey. Nairobi: Central Bureau of Statistics. Ministry of Planning and National Development.

Republic of Kenya. (2008) Labor force analytical report: based on the kenya integrated household budget survey 2005/06. Nairobi: Kenya National Bureau of Statistics.

Ministry of Health (2014) Kenya health policy 2014-2030: towards attaining highest standards of heath. Nairobi: Ministry of Health.

Robertson, D., \& Symons, J. (1990). The occupational choice of british children. The Economic Journal, 100, 828-841. 
Thomas, D., \& Strauss, J. (1997). Health and wages: evidence on men and women in urban Brazil. Journal of Econometrics, 77, 159-185.

Vijverberg, W. (1993). Educational investments and returns for women and men in Co^ te d'Ivoire, Journal of Human Resources, 28, 933-974.

Wambugu, A. (2011). The effects of educational attainment on employment outcomes in Kenya. International Journal of Education Administration and Policy, 3, 94-102.

Wamuthenya, R.W. (2010). Determinants of formal and informal sector employment in the urban areas of Kenya. AERC Research Paper 194. Nairobi: African Economic Research Consortium.

World Bank. (2012) World development report 2013: jobs. Washington, DC: World Bank.

Wooldridge, J.M. (2002). Econometric Analysis of Cross Section and Panel Data: The MIT Press.

Zissimopoulos, J., \& Karoly, L. (2007). Transitions to self-employment at older ages: the role of wealth, health, health insurance and other factors, Labour Economics, 14, 269-295.

Zucchelli, E., Harris M., \& Xueyan, Z. (2012). Ill-Health and transitions to part-time work and self-employment among older workers. Health, Econometrics and Data Group WP 12/04. 


\section{Appendix}

Hausman tests of Independence of Irrelevant Alternatives (IIA) assumption

Null hypothesis: Odds (Outcome-J vs Outcome-K) are independentof other alternatives.

\begin{tabular}{llcll}
\multicolumn{1}{c}{ Table A1: } & Hausman test, Chronic Illness & & \\
\hline Omitted & $\chi^{2}$ & $\begin{array}{c}\text { Degree of } \\
\text { freedom }\end{array}$ & $\mathrm{p}>\chi^{2}$ & Evidence \\
\hline Wage employment & -246.296 & 13 & 1.000 & For Ho \\
Non-agricultural self-employment & 717.329 & 12 & 0.000 & Against Ho \\
Agricultural self-employment & 0.163 & 24 & 1.000 & For Ho \\
Not working & 820.667 & 24 & 0.000 & Against Ho \\
\hline \hline
\end{tabular}

\section{Likelihood ratio for combining outcome categories}

Null hypothesis: All coefficients except intercepts associated with given pair of outcomes are zero (i.e., categories can be collapsed).

Table A2: $\quad$ LR Test for Combining Employment Outcome Categories, Chronic Illness

\begin{tabular}{lccc}
\hline Categories tested & $\chi^{2}$ & $\begin{array}{c}\text { Degrees of } \\
\text { freedom }\end{array}$ & $p>\chi^{2}$ \\
\hline Wage employment-non-agricultural self-employment & 303.952 & 12 & 0.0000 \\
Wage employment - agricultural self-employment & 1764.063 & 12 & 0.0000 \\
Wage employment-Not working & 1316.955 & 12 & 0.0000 \\
Non-agricultural self-employment - agricultural self - & & & \\
employment & 1314.780 & 12 & 0.0000 \\
Non-agricultural self-employment -Not working & 668.383 & 12 & 0.0000 \\
Agricultural self-employment- Not working & 1310.324 & 12 & 0.0000 \\
\hline \hline
\end{tabular}


Table A3:

Test of Statistical Difference between Coefficients in the Gender Models

Dependent variable: types of employments

The null hypothesis: Interaction terms are jointly equal to zero

\begin{tabular}{|c|c|c|c|}
\hline \multirow[b]{2}{*}{ Chronic illness } & \multicolumn{3}{|c|}{ Health status=chronic illness } \\
\hline & $\begin{array}{l}-0.3998 * * * \\
{[0.091]}\end{array}$ & $\begin{array}{l}-0.0952 \\
{[0.087]}\end{array}$ & $\begin{array}{l}-0.3055^{* * *} \\
{[0.082]}\end{array}$ \\
\hline \multicolumn{4}{|l|}{ Acute illness } \\
\hline Gender (Male=1) & $\begin{array}{l}0.2117^{* * * *} \\
{[0.019]}\end{array}$ & $\begin{array}{l}0.2095^{* * * *} \\
{[0.019]}\end{array}$ & $\begin{array}{l}0.1272^{* * *} \\
{[0.016]}\end{array}$ \\
\hline Age & $\begin{array}{l}-0.0025^{* * *} \\
{[0.000]}\end{array}$ & $\begin{array}{l}-0.0024 * * * \\
{[0.000]}\end{array}$ & $\begin{array}{l}-0.0013^{* * *} \\
{[0.000]}\end{array}$ \\
\hline Age squared & $\begin{array}{l}1.5801^{* * * *} \\
{[0.414]}\end{array}$ & $\begin{array}{l}1.9357^{* * * *} \\
{[0.449]}\end{array}$ & $\begin{array}{l}2.1182^{* * * *} \\
{[0.385]}\end{array}$ \\
\hline Primary education & $\begin{array}{l}0.1904^{* *} \\
{[0.078]}\end{array}$ & $\begin{array}{l}0.1136 \\
{[0.077]}\end{array}$ & $\begin{array}{l}0.1524^{* *} \\
{[0.067]}\end{array}$ \\
\hline Secondary education & $\begin{array}{l}0.3033^{* * * *} \\
{[0.091]}\end{array}$ & $\begin{array}{l}-0.0089 \\
{[0.094]}\end{array}$ & $\begin{array}{l}-0.0168 \\
{[0.088]}\end{array}$ \\
\hline Tertiary education & $\begin{array}{l}1.1767^{* * * *} \\
{[0.098]}\end{array}$ & $\begin{array}{l}-0.0807 \\
{[0.111]}\end{array}$ & $\begin{array}{l}-0.3331^{* * *} \\
{[0.118]}\end{array}$ \\
\hline Married dummy & $\begin{array}{l}-0.8168 * * * \\
{[0.069]}\end{array}$ & $\begin{array}{l}-0.097 \\
{[0.072]}\end{array}$ & $\begin{array}{l}-0.1715^{* *} \\
{[0.067]}\end{array}$ \\
\hline 1 child ( $0-5$ years) & $\begin{array}{l}-0.117 \\
{[0.073]}\end{array}$ & $\begin{array}{l}-0.1501^{* *} \\
{[0.076]}\end{array}$ & $\begin{array}{l}-0.2763^{* * *} \\
{[0.071]}\end{array}$ \\
\hline \multirow[t]{2}{*}{$\begin{array}{l}\text { Two or more children (0-5 } \\
\text { years) }\end{array}$} & $-0.2533 * * *$ & $-0.1853^{* *}$ & $-0.1761 * *$ \\
\hline & [0.088] & {$[0.088]$} & [0.075] \\
\hline Rural area & $\begin{array}{l}-0.0837 \\
{[0.065]}\end{array}$ & $\begin{array}{l}-0.3055^{* * *} \\
{[0.067]}\end{array}$ & $\begin{array}{l}1.8294 * * * \\
{[0.074]}\end{array}$ \\
\hline Transfers & $\begin{array}{l}0.0266 \\
{[0.067]}\end{array}$ & $\begin{array}{l}0.0409 \\
{[0.069]}\end{array}$ & $\begin{array}{l}-0.3146^{* * *} \\
{[0.062]}\end{array}$ \\
\hline Maled*Chronic illness & $\begin{array}{l}0.1943 \\
{[0.133]}\end{array}$ & $\begin{array}{l}-0.0828 \\
{[0.138]}\end{array}$ & $\begin{array}{l}0.1006 \\
{[0.129]}\end{array}$ \\
\hline \multicolumn{4}{|l|}{ Maled*Acute illness } \\
\hline Maled*Age & $\begin{array}{l}-0.0445^{*} \\
{[0.025]}\end{array}$ & $\begin{array}{l}-0.0978^{* * *} \\
{[0.027]}\end{array}$ & $\begin{array}{l}-0.0972 * * * \\
{[0.023]}\end{array}$ \\
\hline Maled*Age squared & $\begin{array}{l}0.0003 \\
{[0.000]}\end{array}$ & $\begin{array}{l}0.0010^{* * * *} \\
{[0.000]}\end{array}$ & $\begin{array}{l}0.0010^{* * * *} \\
{[0.000]}\end{array}$ \\
\hline Maled*Primary education & $\begin{array}{l}-0.2689^{* *} \\
{[0.107]}\end{array}$ & $\begin{array}{l}-0.1433 \\
{[0.113]}\end{array}$ & $\begin{array}{l}-0.2311^{* *} \\
{[0.098]}\end{array}$ \\
\hline Maled*Secondary education & $\begin{array}{l}-0.3892^{* * *} \\
{[0.123]}\end{array}$ & $\begin{array}{l}0.0128 \\
{[0.132]}\end{array}$ & $\begin{array}{l}-0.1234 \\
{[0.123]}\end{array}$ \\
\hline Maled* Tertiary education & $\begin{array}{l}-0.5856^{* * *} \\
{[0.138]}\end{array}$ & $\begin{array}{l}0.1773 \\
{[0.156]}\end{array}$ & $\begin{array}{l}0.0347 \\
{[0.161]}\end{array}$ \\
\hline Maled* Marital status dummy & $\begin{array}{l}1.6424^{* * *} \\
{[0.108]}\end{array}$ & $\begin{array}{l}1.1723^{* * * *} \\
{[0.119]}\end{array}$ & $\begin{array}{l}0.7548^{* * * *} \\
{[0.111]}\end{array}$ \\
\hline Maled* One child ( $0-5$ years) & $\begin{array}{l}0.0086 \\
{[0.104]}\end{array}$ & $\begin{array}{l}0.2037^{*} \\
{[0.111]}\end{array}$ & $\begin{array}{l}0.1369 \\
{[0.105]}\end{array}$ \\
\hline \multirow[t]{2}{*}{$\begin{array}{l}\text { Maled* Two or more children } \\
(0-5 \text { years })\end{array}$} & -0.0688 & 0.0118 & 0.1102 \\
\hline & {$[0.122]$} & [0.128] & [0.113] \\
\hline Maled* Rural area & $\begin{array}{l}-0.2169^{* *} \\
{[0.089]}\end{array}$ & $\begin{array}{l}-0.0198 \\
{[0.096]}\end{array}$ & $\begin{array}{l}-0.2842^{* * *} \\
{[0.107]}\end{array}$ \\
\hline Maled* Transfers & $\begin{array}{l}0.0084 \\
{[0.091]}\end{array}$ & $\begin{array}{l}-0.0578 \\
{[0.098]}\end{array}$ & $\begin{array}{l}0.0843 \\
{[0.089]}\end{array}$ \\
\hline Constant & $\begin{array}{l}-4.1124 * * * \\
{[0.303]}\end{array}$ & $\begin{array}{l}-4.3929 * * * \\
{[0.312]}\end{array}$ & $\begin{array}{l}-3.6388 * * * \\
{[0.267]}\end{array}$ \\
\hline Observations & 11,230 & 11,230 & 11,230 \\
\hline$\chi^{2}$ & 3691.35 & 3691.35 & 3691.35 \\
\hline
\end{tabular}

